\title{
Early Christian Iconography in Raphael’s Disputà
}

\author{
Bonnie L. Kutbay \\ Mansfield University of Pennsylvania, Mansfield, PA, USA
}

\begin{abstract}
The theme of Raphael's Disputà del Sacramento (Disputation of the Holy Sacrament) has perplexed scholars over the years. Though the subject of theology has been mentioned, no one has shown in depth how the painting reflects theology or how the figures work together to present a unified theme on theology. Questions remain concerning the broader theological meaning of the Disputà. This study will reexamine the material and offer a deeper interpretation based on early Christian iconography and a study of figures from early Church history. From an early Christian point of view, it will be shown how the presence of specific figures in the Disputà explain the Eucharistic tradition through apostolic succession since the time of the early Church.
\end{abstract}

Keywords: Raphael, Disputà, Eucharist, Eucharistic Adoration, apostolic succession

\section{Introduction}

Scholars have yet to give a clear and concise meaning of Raphael's Disputà del Sacramento (Disputation of the Holy Sacrament) (Figure 1), located in the library room known as the Stanza della Segnatura in the Vatican Apostolic Palace, painted 1509-1510 during the papacy of Julius II (1503-1513) (Joost-Gaugier, 2002). Giorgio Vasari, in his Le vite de' più eccellenti pittori, scultori ed architettori (Lives of the Most Excellent Painters, Sculptors, and Architects) written in 1568, first called the room the Stanza della Segnatura, and first named the fresco, Disputà del Sacramento (Disputation of the Holy Sacrament). Vasari thought the Disputà depicted a debate about the Holy Sacrament, but later scholars suggested the triumph of theology and the original history of the church (Rowland, 2005; Oberhuber, 1999; Gombrich, 1972; Beck, 1993). ${ }^{1}$ It will be shown later in the text that the figures around the altar are participating in Eucharistic Adoration, not a dispute.

Though it is obvious that the Disputà is about theology because of the presence of the Eucharist on the altar, no one has ever explained how the fresco develops a theme of theology or how the figures work together to present theology. Even more problematic is that not all figures have been identified (Joost-Gaugier, 2002). However, the figures who can be identified present an intricate story of the development of the early Church. They are not merely people from Church history placed at random. Each figure has a meaning relative to a central theme and none of this has ever been discussed. The author proposes that early Christian iconography explains why many figures are present and how they work together to present a unified theme of Eucharistic tradition through apostolic succession since the time of the early Church.

Bonnie L. Kutbay, Ph.D. in Art History, professor, Department of Art, Mansfield University of Pennsylvania, Mansfield, PA, USA.

${ }^{1}$ Harry B. Gutman (1942, pp. 35-48) and John Pope-Hennessy (1970) thought the program was derived from St. Bonaventure (1221-1274), an important Franciscan. 


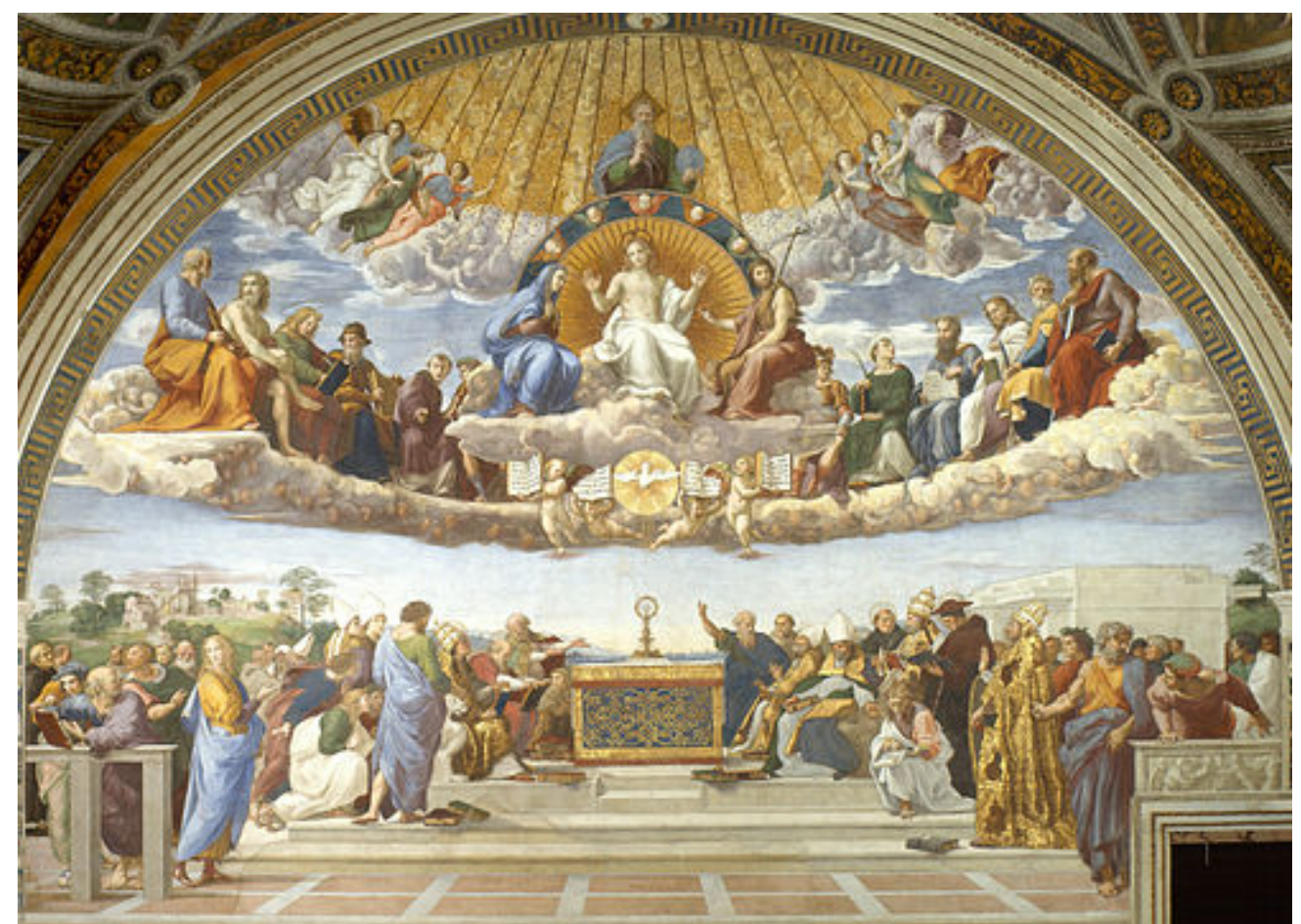

Figure 1. Raphael. Disputà del Sacramento, 1509-1510, fresco, $500 \times 770$ cm, Stanza della Segnatura, Vatican Museums, Rome. Photograph courtesy of Wikimedia Commons (Public Domain).

This article will examine the early Christian iconography of Raphael's Disputà with specific attention to stylistic features and early Church Fathers who wrote extensively on the formation of the early Church and its central focus on the Eucharist. The scope of the paper will be limited to early Christian aspects of the Disputà. Literary sources on the Eucharist, recorded by Apostolic Fathers who are present in the Disputà, confirm the Eucharist as the Real Presence of Christ and as the spiritual nucleus of Catholicism. Their writings also reflect the message of the validity of the Eucharist through apostolic succession (the uninterrupted transmission of spiritual authority from the apostles, instituted by Jesus, through successive bishops and popes). The presence of the Twelve at the Last Supper, when the sacrament of the Eucharist was first instituted, granted them the authority to preside at the Eucharistic celebration. As the apostolicity of the Church continued through time, it gave validity to those in succession to minister the sacrament of the Eucharist. The Eucharist is invalid without apostolic succession.

By celebrating the Eucharist in a visual framework of early Christian imagery, the Disputà emphasizes the authority of the Catholic Church in Rome through the apostolic succession that descended from St. Peter, the first bishop of Rome. It then passed from each successive bishop to bishop, down to Pope Julius II (the bishop of Rome), thus establishing the authority of the Catholic Church and the Papal States in Rome at a time when Rome was facing military threats from neighboring cities and countries.

\section{Early Christian Features of Disputà}

The Stanza della Segnatura is one of four rooms or stanze, all four originally intended as a suite of apartments for Pope Julius II who commissioned Raphael to redecorate the existing interiors of the rooms from 
1508 to 1511 (Taylor, 2009; Beck, 1993). This room, measuring $640 \times 823 \mathrm{~cm}$, was the private papal library of Julius II. $^{2}$ Each of the four walls was decorated with a theme. Theology (Disputà) is on the west wall and was the first to be painted (Joost-Gaugier, 2002). Philosophy (The School of Athens) is on the east wall, poetry (Parnassus) is on the north wall, and law (Jurisprudence) is on the south wall. Theology, philosophy, poetry, and law were the four principle subjects represented in a Renaissance library (Taylor, 2009). The books painted in the frescoes on the walls have titles found in inventory lists that belonged to the papal library (Taylor, 2009; Joost-Gaugier, 2002).

Though no concrete evidence exists for the designer of the four wall frescoes in the Stanza della Segnatura, scholars have suggested that the design and iconography may have been influenced by one or more humanist advisors. ${ }^{3}$ Names include Tommaso “Fedro” Inghirami (Julius’ librarian), Cardinal Egidio da Viterbo (Pfeiffer, 1975), Cristoforo Marcello (Joost-Gaugier, 2002), and Cardinal Marco Vigerio (Gutman, 1942).

The Disputà (1508-1510) measures $500 \times 770 \mathrm{~cm}$ (Figure 1). Along this wall were placed Julius' books on theology (Taylor, 2009). The placement of the fresco on the west wall recalls a similar treatment in early Christian churches built under Constantine (r. 306-337 CE) whose altars stood at the west end of the building within the apse (Joost-Gaugier, 2002). In fact, the apse of Old St. Peter's, located at the west end, was still standing when Raphael was in Rome. ${ }^{4}$ Furthermore, it was decorated with an early Christian mosaic that shares some elements with the Disputà. Early Christian features in the Disputà seem to indicate that Raphael wanted to connect his fresco with early Christian Rome, St. Peter (founder of the Church in Rome), Constantine (builder of St. Peter's Basilica over the grave of St. Peter), and the early days of Christianity that established Eucharistic tradition. Though the wall that bears the Disputà is flat, stylistically it appears to curve as if it is an apse wall in a church. This design seems to have been intentional to recall early Christian church design.

The Disputà displays certain early Christian features. One is the presence of Jesus as youthful and blond like Apollo, an ancient god associated with the sun and light. Apollo was a model for some of the earliest depictions of Jesus. Early Christian examples that Raphael may have seen are the fourth-century CE apse mosaic of Jesus giving the law to St. Peter in Sta. Constanza in Rome (Figure 2), the fifth-century mosaic (c. 425 CE) of Christ as the Good Shepherd in the Mausoleum of Galla Placidia in Ravenna, and the sixth-century CE mosaic of the Miracle of the Loaves and Fishes in Sant' Apollinare Nuovo, Ravenna. In the Disputà, Jesus portrayed with bare torso in heroic half nudity recalls ancient statues of Apollo and Zeus.

\footnotetext{
2 The first writer to describe the library of Julius II, soon after its completion, was the Venetian humanist and future cardinal Pietro Bembo (Joost-Gaugier, 2002, p. 14). In a letter he wrote in 1523, Bembo praised Julius in his efforts to create a great library. He did not describe the books, but only said the room was decorated with paintings and statues.

${ }^{3}$ Few documents exist that support any activity in the Stanza della Segnatura. There is one document of payment to Raphael dated January 13, 1509 for work he completed in the Stanza della Segnatura (Joost-Gaugier, 2002, p. 10). This indicates that Raphael must have started working in the room by 1508. Another document dated October 4, 1509 indicates Raphael working in the room.

${ }^{4}$ Bramante began to demolish only part of Old St. Peter's, and laid the cornerstone and the four central piers in 1506. Later drawings by Maarten van Heemskerck of St. Peter's in the 1530s depict mostly the Old St. Peter's still standing. One drawing shows an interior view of columns in the nave supporting a nave wall covered in either mosaic or frescoes. Further west is the old apse. The only new features in the drawing are the four huge piers along the nave wall, destined to support the future dome. Old parts of Old St. Peter's were demolished as the builders needed to make room for the new features for the new St. Peter's (Boorsch, 1982/83, pp. 1-67).
} 


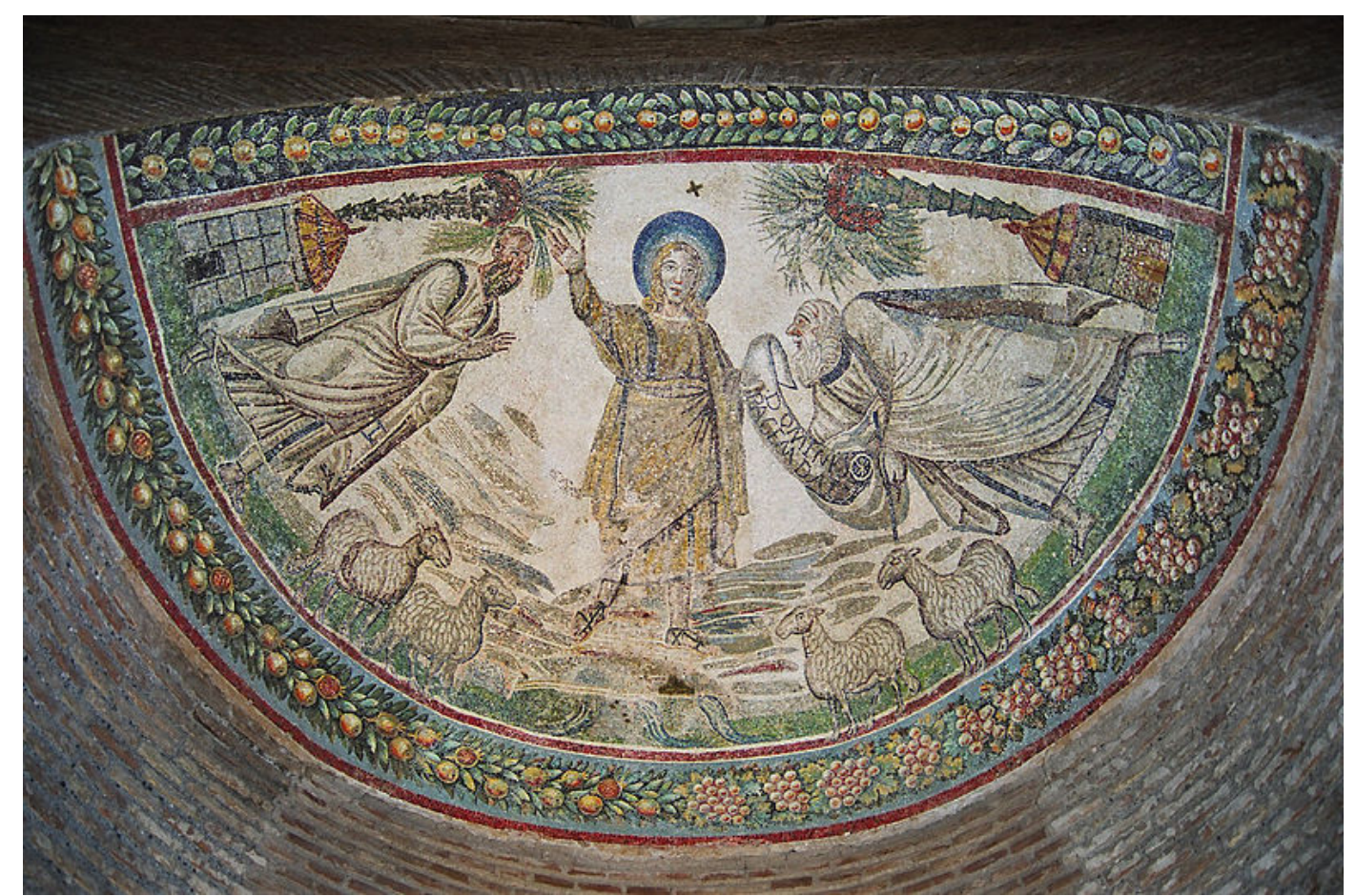

Figure 2. Christ Giving the Law to St. Peter, fourth century. Apse mosaic. Santa Costanza, Rome. Wikimedia Commons (photo: emv).

The profusion of other worldly gold streaming down from a heavenly realm in the upper portion of the Disputà is a common feature in early Christian apse mosaics. We know from the Liber Pontificalis that the apse of the Old St. Peter's Basilica was decorated with gold mosaic (Beckwith, 1979). In the Disputà, the golden area is further defined by geometric vertical bands that radiate downward and outward, recalling the canopy of heaven motif known in early Christian, Byzantine, and Medieval apse mosaics. This realm represents the highest heaven and is frequently suspended above the physical heaven, sometimes portraying the hand of God emerging and pointing downward (Lehmann, 1945).

A very early example of a canopy of heaven motif was found in the apse mosaic of Old St. Peter's Basilica dating to the fourth century CE (Figure 3) (Lehmann, 1945). It consisted of flaring vertical bands terminating in pointed scalloped edges. The mosaic portrayed Jesus enthroned, flanked by St. Peter and St. Paul and two palm-trees; below, the Lamb of God stood flanked by twelve Apostle-lambs between the cities of Jerusalem and Bethlehem. Raphael may have seen it. The original mosaic was restored by Pope Severinus (640 CE) and replaced by Pope Innocent III (pope from 1198-1216) (Beckwith, 1979). The seventh-century CE apse mosaic and the thirteenth-century apse mosaic may have repeated the original late fourth-century CE mosaic, with Christ seated in majesty below the heavenly canopy, and flanked by St. Peter and St. Paul and two palm trees (Krautheimer, 2000). 


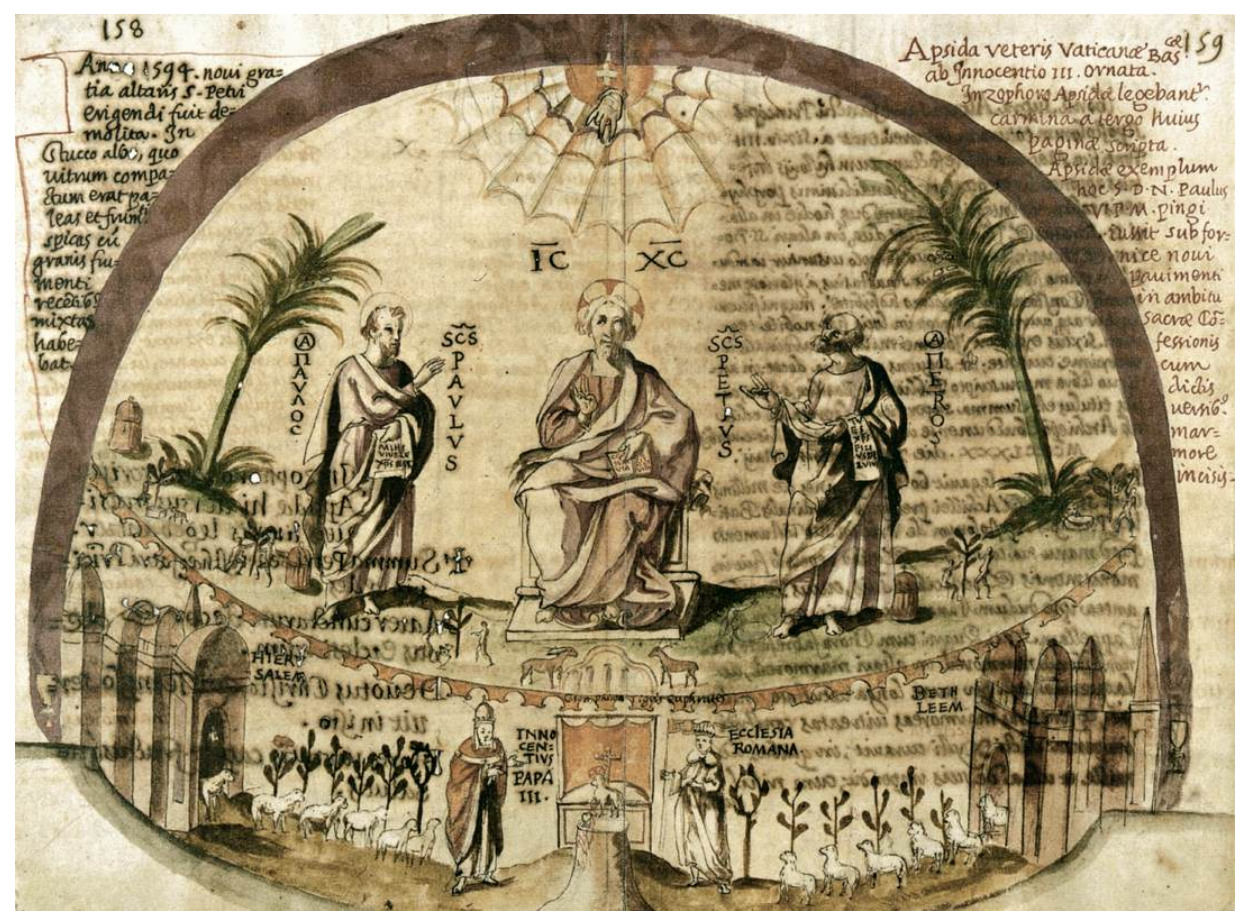

Figure 3. Christ with St. Peter and St. Paul. Original fourth century CE. Watercolor of the apse mosaic from Old St. Peters by Giacomo Grimaldi. Biblioteca Apostolica Vaticana, Barb. Lat. 2733, fols. 158v-159r.

The apse mosaic under Pope Innocent III remained in place until the late sixteenth century when it was demolished due to the building of the new St. Peter's (Krautheimer, 2000). When Pope Paul V (pope from 1606-1621) ordered in 1605 the rest of Old St. Peter's destroyed at the east end to make room for Carlo Maderno's new nave, completed in 1612, he had copies made of all the artwork (Boorsch, 1982/83). Giacomo Grimaldi, a priest, made copies and provided a description of the apse mosaic, indicating that he was making a copy of the older apse from the time of Innocent III. ${ }^{5}$

The Disputà shares a similar composition with the apse mosaic from Old St. Peter's. Both designs depict figures that occupy a heavenly realm that is separated from an earthly realm by an upward curving ground line. In the heavenly realm of the Old St. Peter's mosaic, Jesus is enthroned and flanked by standing figures of St. Peter and St. Paul and two palm-trees. Above them is a canopy of heaven, presented as lines radiating downward and outward like a fan, terminating in pointed scalloped edges. The hand of God the Father issues from the crown. In the Disputà, Jesus and saints (including Peter and Paul at each end) occupy the heavenly realm beneath a canopy of heaven that portrays not the hand of God, but the full figure of God the Father. The lower curved border of the canopy of heaven is obscured by rolling clouds and putti. Below in the earthly realms of both compositions are buildings. In the Old St. Peter's mosaic there are structures on each side, labeled Jerusalem and Bethlehem that flank a figure of Innocent III and a figure of Ecclesia Romana (the Church of Rome). The Disputà also portrays what may be the early construction stages of the new St. Peter's Basilica (the Church of Rome). ${ }^{6}$

\footnotetext{
5 Biblioteca Apostolica Vaticana, Barb. Lat. 2733, fols. 158v-159r.

${ }^{6}$ In the Disputà, the construction of a building in the background, at the left, may be a reference to Julius II as a builder of the new church of St. Peter's (Singer, 1998, p. 199). Another possible reference to St. Peter's is the colossal white marble blocks in the background, at the right, which may be the cornerstone of Saint Peter's that was laid down in 1506, or the half-built piers that were there in 1509 (King, 2002, p. 143).
} 
Similar canopies of heaven with pointed scalloped edging occur in the apse mosaic of the Coronation of the Virgin in the Basilica di Santa Maria Maggiore, by Jacopo Torriti (1295), with parts from the original mosaic dating from the fifth century CE (Figure 4), and also in the apse mosaic of Christ Pantokrator in Sant' Ambrogio Basilica in Milan dating originally to the fourth through eighth centuries CE (Figure 5), with later restorations during the seventeenth and twentieth centuries. Later examples appear in the apse mosaics of Santa Maria in Trastevere in Rome dating from the twelfth century, and in San Clemente in Rome, from the twelfth century.

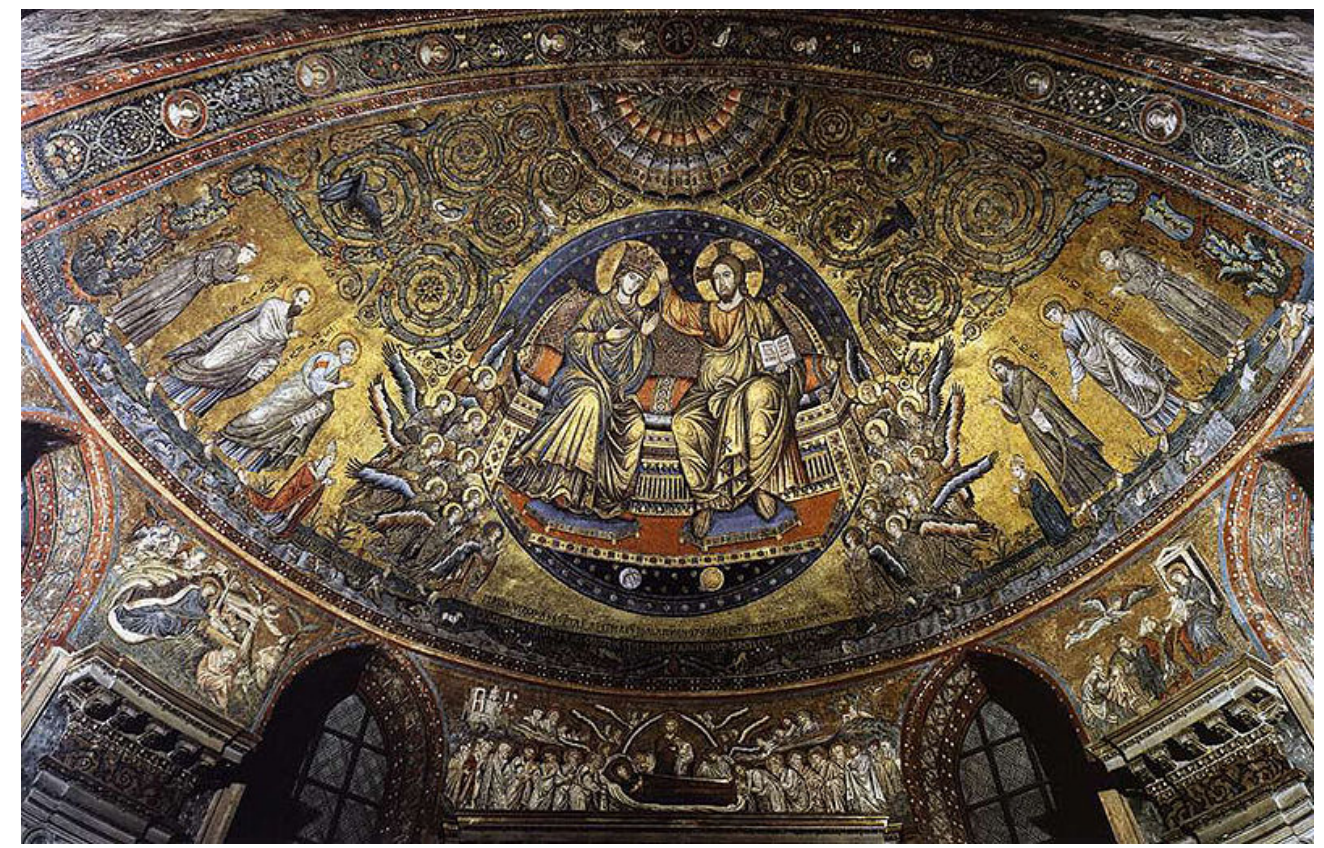

Figure 4. Jacopo Torriti. Coronation of the Virgin, 1295, with parts from the original mosaic of the fifth century CE. Apse mosaic. Basilica di Santa Maria Maggiore, Rome.Wikimedia Commons (Public Domain).

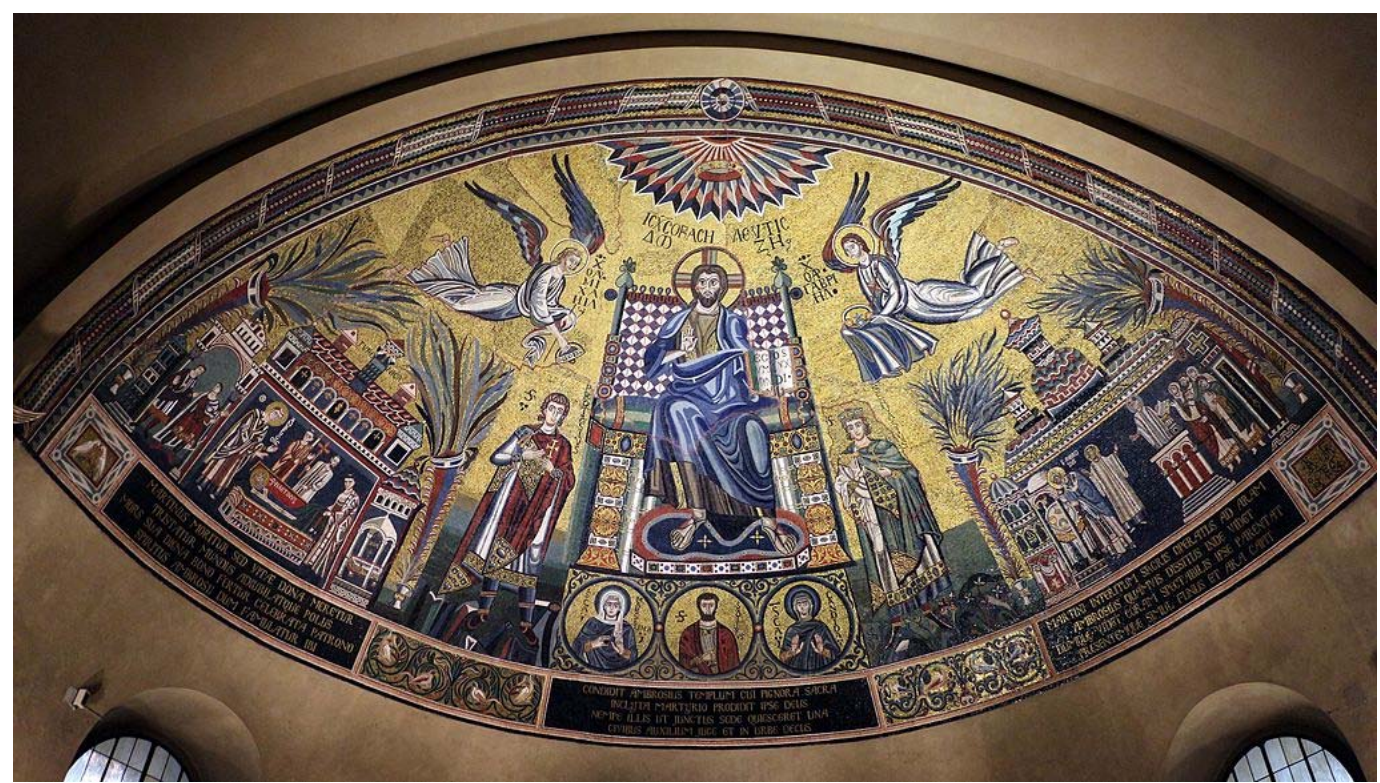

Figure 5. Christ Pantokrator, dating originally to the fourth through eighth centuries CE, with later restorations during the seventeenth and twentieth centuries. Apse mosaic. Sant' Ambrogio Basilica, Milan. Wikimedia Commons (photo: Sailko). 


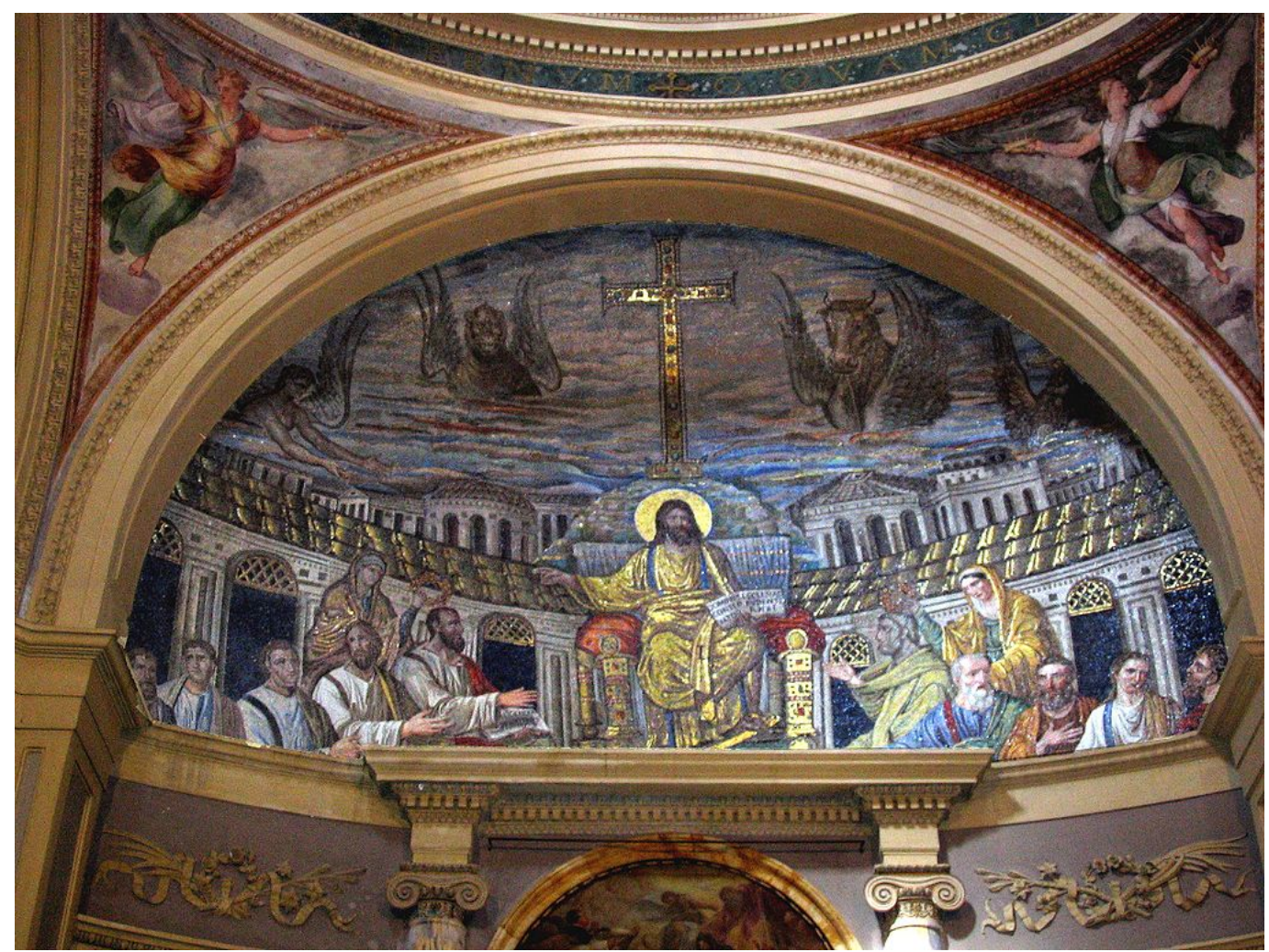

Figure 6. Christ and Apostles, fourth century CE. Apse mosaic. Church of Santa Pudenziana, Rome. Wikimedia Commons (Public Domain).

The curving composition of Jesus and the figures in the heavenly realm in the Disputà recalls the apse mosaic of Christ Enthroned among the Apostles (c. 420 CE) in the church of Sta. Pudenziana in Rome (Figure 6). This may be the earliest surviving figural mosaic in a Roman church (Webb, 2010). André Graber described the semicircular arrangement of Christ and apostles as a collective portrait that first appeared in early Christian art during the third and fourth centuries $\mathrm{CE}$, and whose origins go back to the ancient group portraits of the Hellenistic period (Graber, 1968). ${ }^{7}$ It is found in an early Christian fresco of Christ with apostles in the catacomb of Domitilla in Rome dating from the fourth century CE. In the Disputà, the early Christian formula of the semicircular group portrait shows Christ enthroned among saints, apostles, and men who are relevant to the development of Christianity.

The early Christian motif of a mandorla, a circular or oval light that surrounds the entire body of a figure to show divinity, occurs in the Disputà. Mandorlas that enclose Jesus first appear in art around the middle of the fourth century CE (Jenson, 2000). In the Disputà, Jesus is surrounded by a circular mandorla. It resembles the circular mandorla that surrounds the cross of the transfiguration in the apse mosaic of Sant'Apollinare in Classe in Ravenna, dating c. 533-549 CE (Figure 7). Another circular mandorla, enclosing Jesus and Mary, appears in the apse mosaic of the Coronation of the Virgin in Santa Maria Maggiore in Rome (Figure 4).

\footnotetext{
7 The works show a group of people (philosophers, poets, doctors, teachers surrounded by disciples) seated in a semicircle within an exedra or apse.
} 


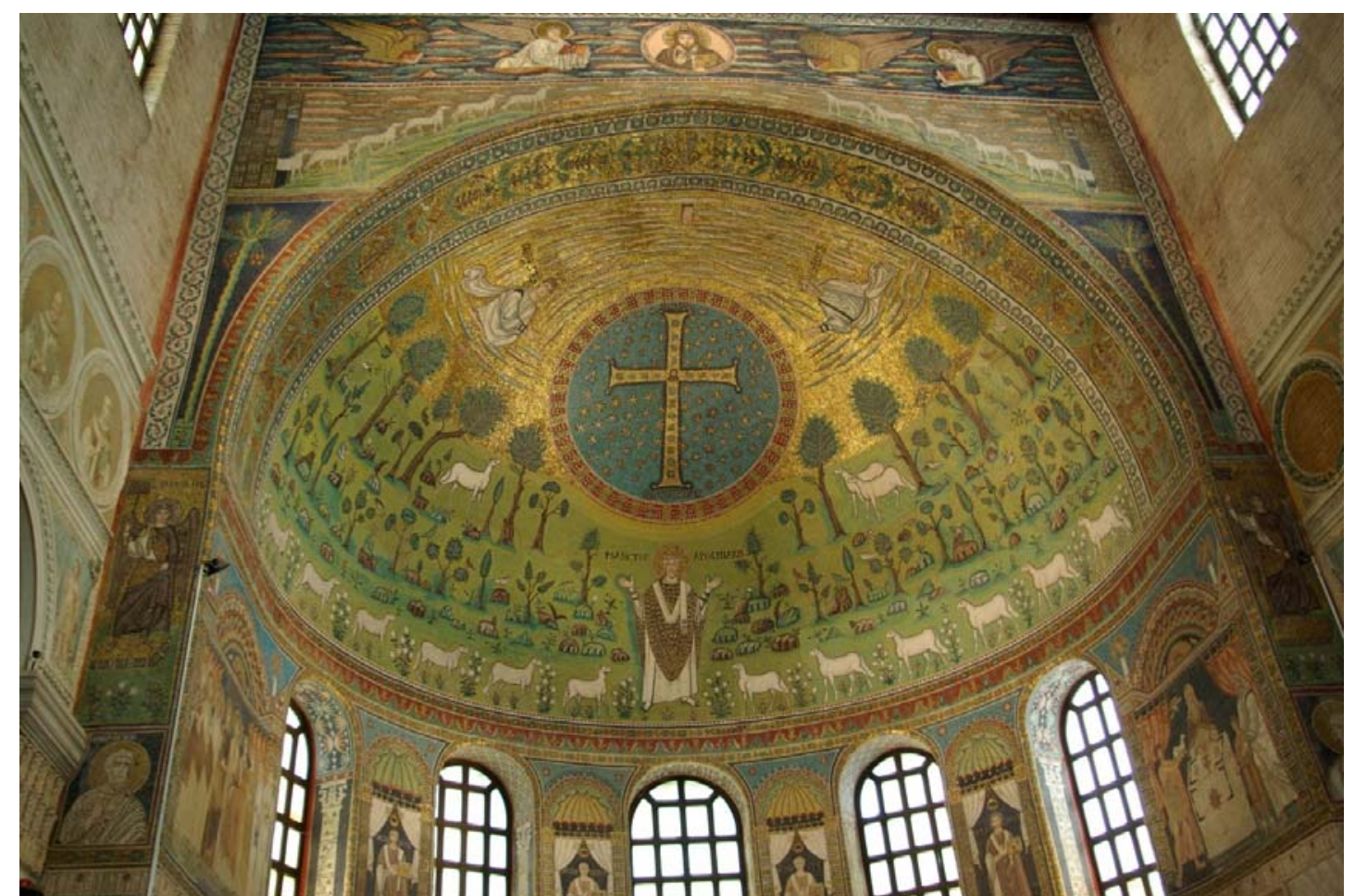

Figure 7. St. Apollinaris amid sheep, c. 533-549 CE. Apse mosaic. Sant'Apollinare in Classe, Ravenna, Italy. Wikimedia Commons (Public Domain).

Raphael chooses an early Christian motif to emphasize the divinity of Jesus and the heavenly light that he radiates. $^{8}$ Similar circular shields of heaven surround Jesus in his depiction as Cosmocrator, ruler of the cosmos.

Heavenly light also radiates from the canopy of heaven in the Disputà. Early Christians saw the presence of the divine in light. ${ }^{9}$ This concept was also shared by Neoplatonism. Founded by Plotinus (204-270 CE), Neoplatonism was a philosophy stemming from the ideas of Plato and shaped by Plotinus (The Enneads). It influenced the development of Christianity. ${ }^{10}$ Neoplatonism believed in the One as the source for all things - beauty, good, truth, and wisdom. The One, equated with God, the Source, Light, and Divine Mind, emanates illumination and with it matter and ideas that contain spiritual truth of divine goodness. In his The Divine Names (IV. 697C), Pseudo-Dionysius the Areopagite equates light with God and the Good. In On the Celestial Hierarchy (124A), Dionysius equates divine beauty with light.

An early Christian motif of the traditio legis (the giving of the laws) is seen in Peter with a book who sits at the far left in the divine realm. The traditio legis refers to the passing of the laws from Jesus to Peter, establishing

\footnotetext{
${ }^{8}$ The circular mandorla resembles the ancient circular shield with a border (clipeus), that represents an image of the revolving cosmos. This shield of heaven (clipeus caelestis), which represents a circular symbol of the universe, is mentioned in ancient Roman literature and is found on ancient Roman sculptures, some bordered with signs of the zodiac encircling images of Jupiter, and some found on sarcophagi surrounding the deceased (L’Orange, 1982, p. 90).

9 John Chrysostom (d. 407 CE), Archbishop of Constantinople and early Church Father, said (Homilies on the Gospel of John; PG 58), "For if the Son is the true Light, and this Light was Life, this Life was made in Him." Light is associated with wisdom.

${ }^{10}$ Neoplatonism influenced Augustine of Hippo (354-430 CE) in the west and the fourth-century CE Cappadocian early Church Fathers in the east. These included St. Basil the Great (330-379 CE), bishop of Caesarea in Cappadocia, Asia Minor; St. Gregory of Nyssa (335-394 CE), bishop of Nyssa in Cappadocia, Asia Minor; and St. Gregory of Nazianzus (330-390 CE), Archbishop of Constantinople. Neoplatonism greatly influenced Pseudo-Dionysius the Areopagite (late fifth to early sixth centuries CE), a Christian philosopher and a Christian Neoplatonist (Luibheid, 1987).
} 
the legitimacy of the Catholic Church through apostolic succession from bishop to bishop. It is a motif in early Christian art stemming from the fourth century CE. ${ }^{11}$ Peter, holding the keys, portrays the traditio clavium (the giving of the keys) formula also going back to early Christian art of the fourth century CE. It shows Peter's importance in the establishment of the Church as Jesus says to Peter in Matthew 16: 18-19:

And I tell you, you are Peter, and on this rock I will build my church, and the gates of Hades will not prevail against it. I will give you the keys of the kingdom of heaven, and whatever you bind on earth will be bound in heaven, and whatever you loose on earth will be loosed in heaven.

The keys symbolize the spiritual authority given to Peter (to bind and loose) to govern the house of God which is the Church. The keys symbolize papal authority. These examples indicate that by the fourth century CE, the bishop of Rome (the pope) was the successor to St. Peter, the founder of the Roman Church.

The appearance of early Christian motifs in the Disputà-Jesus as a youthful Apollo, the profusion of heavenly gold and divine light radiating from God, the canopy of heaven, the semicircular group portrait, the circular mandorla, the similarity with early Christian apse mosaic compositions (Old St. Peter's and Santa Pudenziana), St. Peter with the traditio legis motif (the giving of the laws), and St. Peter with the traditio clavium motif (the giving of the keys)—connect the Disputà with the early days of the founding of the Church in Rome.

\section{Early Church Fathers and the Eucharist}

To fully understand the theology that is presented in the Disputà, one must be familiar with the writings of the early Church Fathers in the painting who discussed the early Church and the Eucharist. Positioned close to the altar, they include St. Ignatius, St. Irenaeus, ${ }^{12}$ and the Four Great Doctors of the Latin Church identified by inscriptions in their haloes and by books at their feet: St. Ambrose, St. Augustine, St. Jerome, and St. Gregory. ${ }^{13}$ Their writings reflect a common core of belief that presented the Eucharist as the Real Presence of Jesus Christ and as the spiritual nucleus of the Church that remained unchanged up to the time of Julius II.

Early Christians viewed the Eucharist as the bread and wine that becomes the glorified body and blood of Jesus Christ at the time of consecration at Mass during the Eucharistic prayer, whose written origins date back to St. Ambrose c. 375 CE. Eucharistic Prayer I developed from a fourth-century CE Eucharistic prayer found in On the Sacraments 4.6.27 (De sacramentis) by St. Ambrose (c. 340-397 CE), bishop of Milan (374-397 CE), and Doctor of the Church. The seated St. Ambrose is the third figure to the right of the altar in the Disputà. The prayer asks God to accept the present sacrifice as he did those of Abel, Abraham and Melchizedek. It was later modified by St. Gregory the Great, Doctor of the Church and pope from 590 to $604 \mathrm{CE}$, who is the fourth figure (seated) to the left of the altar. Since the time of Gregory, the Eucharistic Prayer I, known as the Roman Canon, has remained unchanged except for minor changes and adjustments.

During consecration, the bread and wine are transformed (transubstantiated) into the body and blood of

\footnotetext{
11 The fourth-century CE apse of St. Peter's basilica may have been decorated with a traditio legis, much like what appears in the fourth-century CE apse of Santa Costanza in Rome.

12 Other opinions are that the gesturing figures near the altar may be St. Justin Martyr and St. Ignatius (bishop) of Antioch (Gutman, 1941, pp. 420-429). The earliest record of the Eucharistic sacrifice is found in the First Apology of Justin Martyr (c. 155 $\mathrm{CE})$.

${ }^{13}$ In 1298 during the pontificate of Pope Boniface VIII, these four early Church Fathers received distinction. Because of their great contributions toward the sacred Scriptures and the development of the Christian doctrine, each attained the title of Doctor of the Latin Church.
} 
Jesus. Known as Transubstantiation, this event occurs at Mass during the Eucharistic Prayer (Roman Canon) when the priest pronounces the words of consecration spoken by Jesus during the Last Supper, “...this is my body...this is my blood...” (Matthew 26: 26-29). The Eucharist is not symbolic of the body and blood of Jesus but is the Real Presence of Jesus under the appearance of bread and wine. It is a memorial of Christ's sacrificial death and resurrection.

The belief in the Real Presence of Christ in the bread and wine of the Eucharist was embraced by the early Church Fathers. They praised the Eucharist as the supreme sacrament of the Mass, as a sacred sacrifice, and as a holy mystery in union with the divine. St. Ignatius (35-108 CE), third bishop of Antioch, said in his Epistle to the Smyrnaeans (Chapter 7), "(the Eucharist) is the bread that is the flesh of Jesus Christ, this flesh which has suffered for our sins." ${ }^{14}$ Ignatius, who stands to the left of the altar in the Disputà, with both arms pointing toward the Eucharist, is known for his passionate statements on the Eucharist recorded in his letters. He wrote seven letters in which he expressed the mystical power of the Eucharist. These are viewed as the most important documents that link the twelve apostles with the early Church (Armenio, 2006).

St. Irenaeus (c. 130-c. $200 \mathrm{CE}$ ), considered one of the greatest theologians of the second century CE, is the first figure to the right of the altar, pointing upward to the heavenly realm. St. Irenaeus, a disciple of St. Polycarp, and possibly from Smyrna, was bishop of Lyons in Gaul from 177 until his martyrdom in c. 200 CE. In his Against Heresies (Adversus haereses) 4.18.5, written 180 CE, St. Irenaeus discusses an earthly bread and a heavenly bread that parallel the earthly and heavenly realms in the Disputà:

For as the bread, which is produced from the earth, when it receives the invocation of God is no longer common bread, but the Eucharist, consisting of two realities, earthly and heavenly; so also our bodies, when they receive the Eucharist, are no longer corruptible, having the hope of the resurrection to eternity. ${ }^{15}$

The third figure to the left of the altar is the seated St. Jerome (345-420 CE) dressed in red and with a halo inscription. At his feet are the Bible and his Letters. In his Commentary on Matthew (4:26:26), Jerome wrote of the bread as the Real Presence. The fourth figure to the right of the altar, is the seated St. Augustine (354-430 CE), bishop of Hippo, with his book, The City of God at his feet. In his Sermons (227) St. Augustine described the bread as the body of Christ. The third figure at the right of the altar is the seated St. Ambrose (340-397 CE), bishop of Milan, with a halo inscription. In his On the Sacraments 4 (De Sacramentis), he wrote that the Eucharist is the true flesh of Christ.

The fourth figure at the left of the altar is the seated Pope Gregory I (540-604 CE), known as St. Gregory the Great, with a halo inscription. At Gregory's feet is the Liber moralium (his commentary on the book of Job). In 595 CE he made changes to the liturgy and codified the standardized version of the Roman Canon. The Canon refers to a formal order of prayers said for the offering of the sacrificed body and blood of Christ to God the Father, just before the Communion part of the Mass. Part of his codification of the Roman Canon included the arrangement of its prayers into the order we see today.

These important Church Fathers from the early Christian period grouped around the altar (St. Ignatius, St. Irenaeus, St. Ambrose, St. Augustine, St. Jerome, and St. Gregory) contributed to the understanding of the

\footnotetext{
14 Translated in Roberts, 1885, loc. 4571.

15 Irenaeus Against Heresies, translated in Roberts, Vol. 1.
} 
Eucharist as the Real Presence of Christ through their writings. The Eucharist as the spiritual focus of the early Church was expressed clearly by St. Irenaeus:

\author{
In brief, the Eucharist is the sum and summary of our faith: "Our way of thinking is attuned to the Eucharist, and the \\ Eucharist in turn confirms our way of thinking”. (Against Heresies 4, 18, 5) ${ }^{16}$
}

\title{
Eucharistic Adoration
}

In the Disputà, the monstrance containing the Eucharistic wafer, seen through its window, occupies a position on the altar much as one finds in settings of Eucharistic Adoration, where only the consecrated bread is present on the altar without the wine, books, and other vessels (the pyx, chalice, and paten) that are normally used during the Communion of the Mass. Eucharistic Adoration is the act of spiritually adoring the Real Presence of Christ in the Eucharist that is visible in the monstrance. The wafer has been consecrated and transubstantiated previously during Mass, so Jesus is sacramentally present. Because of the sanctity of the wafer, it is highly unlikely that a disputation is unfolding as Vasari suggested. The author proposes that the figures around the altar are participating in Eucharistic Adoration, not a dispute. The earliest known evidence of Eucharistic Adoration comes from the second century CE (Hardon, 1997). Surrounding the Eucharist in the earthly realm are people across time, spanning the second century CE up to the time of Julius II, participating in Eucharistic Adoration. The animated actions of the surrounding presiders are not unusual for a Eucharistic Adoration. Common are the recitation of prayers, the readings of prayers, and songs. Kneeling in adoration in silent prayer also occurs.

Though the monstrance on the altar is the vanishing point in the Disputà, the spectator's eye is drawn to Jesus Christ in the heavenly realm, with stigmata, enthroned in glory in a golden mandorla, with God the Father above and the Holy Spirit below, a reference to the Holy Trinity.The presence of the Trinity is necessary for the prayer known as the epiclesis said during the Eucharistic Prayer (Roman Canon) when the Church asks God the Father to send his Holy Spirit on the bread and wine so that by God's power, they are turned into the body and blood of Jesus Christ. In the Disputà, the dove of the Holy Spirit has descended on the monstrance and has transformed the bread during the mystical change of Transubstantiation. Thus, those who eat the sacred bread of the Eucharist become one body and one spirit in mystical unity with Christ.

\section{The Sacred Bread}

Three of the Gospels-Matthew, Mark, and Luke—narrate the significance of the bread at the Last Supper. However, the earliest text mentioning this event is found in the first epistle of St. Paul to the Corinthians, who sits at the far right to Jesus in the heavenly realm. Written c. $57 \mathrm{CE}$, it says:

The Lord Jesus on the night when he was betrayed took a loaf of bread, and when he had given thanks, he broke it and said, "This is my body that is for you. Do this in remembrance of me.” In the same way he took the cup also, after supper, saying, "This cup is the new covenant in my blood. Do this, as often as you drink it, in remembrance of me” (1 Corinthians 11: 23-26).

The body that is present in the Eucharist on the altar in the Disputà, after Transubstantiation, is Christ who now reigns in heaven. His stigmata indicate that the body which died on the cross was resurrected and paved the way for the New Covenant. The Gospels held by the putti, located just below Jesus, refer to the sacred tradition

${ }^{16}$ Irenaeus Against Heresies, translated in Roberts, 1885, loc 17460, ANF01. 
passed on by Jesus to his apostles so they may spread the good news.

The proximity of the many angelic figures to Jesus suggests a Eucharistic connection. Their appearance in the heavenly realm may have a direct reference to the writings of St. Augustine standing below in the earthly realm to the right of the altar. St. Augustine (354-430 CE), bishop of Hippo, described the Eucharist as the bread of angels in his Exposition of the Psalms (78.15), written c. 390s. ${ }^{17}$ The bread of angels first appears in Psalm 78: 23-25 as the manna that the Israelites under Moses ate during their forty years in the desert. The eternal food of angels nourishing men in the desert is a preview of how the bread of angels will nourish men through the Eucharist.

In the Bread of Life Discourse in the Gospel of John (6: 22-59), Jesus explains the significance of the bread that just fed the 5,000 with five loaves and two fish.

Jesus said to them, "I am the bread of life... (John 6: 32-35). This is the bread that comes down from heaven, so that one may eat of it and not die. I am the living bread that came down from heaven. Whoever eats of this bread will live forever; and the bread that I will give for the life of the world is my flesh” (John 6: 49-51).

These relevant passages from St. Augustine and the Gospel of John may explain the presence of St. Augustine, John, and Moses in the Disputà. St. Augustine is the fourth figure seated to the right of the altar, identified by his famous work, De civitate Dei (The City of God) at his feet and dressed in his bishop's mitre and robe. St. John and Moses sit in the heavenly realm with Jesus.

The presence of Matthew in the heavenly realm to the right of Jesus, between Moses and Abraham, may be a reference to the phrase "give us this day our daily bread" found in the liturgical Lord's Prayer that is said at each Mass (Matthew 6: 9-13). While Jesus was preaching to the multitudes during his Sermon on the Mount, he told them how to pray. Jesus said:

Pray then in this way: Our Father in heaven, hallowed be your name. Your kingdom come. Your will be done, on earth as it is in heaven Give us this day our daily bread. And forgive us our debts, as we also have forgiven our debtors. And do not bring us to the time of trial but rescue us from the evil one. (Matthew 6: 9-13)

The daily bread is the Bread of Life which refers to the body of Jesus. A shorter version of the Lord's Prayer is found in Luke 11: 24.

The iconography of the sacred bread is further developed with the presence of David and Abraham in the sacred realm and St. Ignatius (35-108 CE), bishop of Antioch, in the earthly realm. David sits to the left of Jesus between St. John and St. Stephen. Abraham sits to the right of Jesus between St. Matthew and St. Paul. St. Ignatius is the first figure standing to the left of the altar, with arms outstretched towards the monstrance. The presence of all three may be a reference to a letter written to the Romans c. 106 CE by St. Ignatius:

I have no taste for food that perishes nor for the pleasures of this life. I desire the bread of God, the heavenly bread, the bread of life, which is the flesh of Jesus Christ, the Son of God, who became afterwards of the seed of David and Abraham; and I desire the drink of God, namely His blood, which is incorruptible love and eternal life. ${ }^{18}$

\footnotetext{
${ }^{17}$ Exposition of the Psalms, 78.15 translated in Roberts, loc 333266, NPNF 1-08. St. Thomas Aquinas (1225-1274), Dominican priest and philosopher, also describes the Eucharist as the bread of angels in his Lauda Sion Salvatorem, written c. 1264 for the Feast of Corpus Christi.

${ }^{18}$ St. Ignatius was a disciple of St. John the Evangelist and St. Peter. Because of his direct contact with the apostles (Peter and John), Ignatius is an Apostolic Father. He was condemned to death by being fed to lions in the Colosseum during the reign of Trajan. Ignatius was the first to use the term "catholic" to describe the whole Church.
} 
Consuming the sacred bread unites the participant with Jesus Christ. St. Ambrose wrote:

Thus, every soul which receives the bread which comes down from heaven is a house of bread, the bread of Christ, being nourished and having its heart strengthened by the support of the heavenly bread which dwells within it. (Letter to Horontianus, letter 70.13$)^{19}$

\section{Figures From the Heavenly Realm}

Figures in the upper tier of the heavenly realm are associated with the history and development of the early Church. Though scholars have offered suggestions for their identity, none have explained their meaning or how they work together. The author suggests that the theme of the Eucharist as the Real Presence of Jesus unites them. Jesus is flanked by his mother the Virgin Mary and by St. John the Baptist. Mary is presented as the mother of the Incarnate Jesus Christ-Jesus as the begotten son of God who is fully God and fully human as supported in the Nicene Creed formulated at the Council of Nicaea in $325 \mathrm{CE}$ and further confirmed at the Council of Ephesus in $431 \mathrm{CE}$ and at the Council of Chalcedon in 451 CE. St. John the Baptist, who sits to right of Jesus, baptized Jesus in the River Jordan. Baptism is an integral part of the Eucharist. According to St. Paul, it is through baptism that the participant enters into communion with Christ's death, is buried with him, and rises with him (Romans 6: 3-4).

Surrounding the Virgin Mary and St. John the Baptist (from left to right for the viewer) are figures from the Old Testament and New Testament: St. Peter (with a book and key), Adam (with legs crossed), St. John the Evangelist (in the act of writing), King David (with a stringed instrument), St. Stephen (Joost-Gaugier, 2002), and the Prophet Jeremiah. ${ }^{20}$ On the right side of Jesus are Judas Maccabeus in armor, St. Lawrence with the gridiron under his right arm, Moses with the tablets of the Ten Commandments, St. Matthew with a book, Abraham with a knife, and St. Paul with his sword. Each person in the heavenly realm is relevant to history of the formation of the early Church associated with Jesus.

Adam, Abraham, David, and Moses provide the Jewish lineage that will lead to the birth of Jesus. Jeremiah, the prophet, will predict the coming of Jesus. Jeremiah is considered by many to be the major Old Testament prophet of the New Covenant.

The days are surely coming, says the Lord, when I will raise up for David a righteous branch, and he shall reign as king and deal wisely, and shall execute justice and righteousness in the land. (Jeremiah 23: 5)

The presence of the patriarch Abraham recalls the promise of God to Abraham to make him a father of many nations. Abraham's son, Isaac, and his grandson, Jacob, and their offspring led to the multitude of nations that ultimately led to the royal lineage of King David and Jesus Christ. Abraham sits next to Matthew. Matthew in his Gospel (1: 1-17) calls Jesus the son of David and the son of Abraham. Abraham shows the importance of God's promise to Abraham - his numerous descendants with whom God would make an everlasting covenant to be their God, and, "I will make you exceedingly fruitful, and I will make nations of you, and kings shall come forth from you” (Genesis 17: 6).

The apostles Peter, John, and Matthew, members of the original twelve apostles, knew Jesus and were

\footnotetext{
19 Ambrose, Letter to Horontianus, c. 387 CE. Translated in Walford, 1881, p. 416.

20 Paul Taylor (2009, p. 124) suggests it is Joshua since Dante mentions Joshua in Paradisio, 18.38.
} 
instrumental in the spreading of his teachings and early Christianity. Paul, who became an apostle after the Ascension of Jesus, was one of the most important evangelists, writing thirteen books of the twenty-seven books of the New Testament. These are the men who will pass down the teachings of Jesus and the early Church to future generations through a steady line of apostolic succession. Peter, portrayed with a book and keys showing the motifs of traditio legis (the giving of the laws) and traditio clavium (the giving of the keys), reaffirms the passing of the laws and spiritual authority from Jesus to Peter.

To the right of St. John the Baptist is Judas Maccabeus (died 161/160 BCE), Jewish priest from Judea, who is famous for his military victory in vanquishing the Syrians from Judea and saving the Jews from annihilation. ${ }^{21}$ It is a story of the salvation of Israel, told in 1 Maccabees in the Old Testament. Judas, son of the priest Mattathias, rebelled against the Seleucid armies of King Antiochus IV Epiphanes who wanted to impose the Greek religion on Judea. Antiochus wanted to turn the Jerusalem Temple into a temple of Zeus. In the Maccabean Revolt (167-160 BCE), Judas was victorious, liberated Judea and restored the Temple at Jerusalem (Josephus, 12.7.7). The story of the salvation of the Jews paved the way for the coming of Jesus Christ.

St. Stephen and St. Lawrence in the heavenly realm are two of the earliest Christian martyrs. They were two archdeacons who were famous and widely venerated. Their presence is related to the early days of Christianity. St. Stephen, the first Christian martyr, was one of the first deacons ordained by St. Peter in Jerusalem. His preaching angered his enemies who accused him of blasphemy and stoned him to death outside the city walls. The story of the martyrdom of St. Lawrence took place in Rome in the third century CE during the development of the early Church. When the Emperor Decius asked for the treasures from the Church, Lawrence distributed it all to the poor, angering the Romans. Lawrence was punished by being roasted on a gridiron.

\section{Conclusion}

The Disputà resembles an early Christian apse mosaic. Early Christian motifs include Jesus as a youthful Apollo surrounded by a circular mandorla, the profusion of heavenly gold, light radiating from the canopy of heaven, the semicircular group portrait, and the giving of the laws (traditio legis) and the keys (traditio clavium) to St. Peter. Its similarity with early Christian apse mosaics (Old St. Peter's and Santa Pudenziana) connects the Disputà with the early days of the founding of the Church in Rome with St. Peter as its first bishop and the establishment of apostolic succession. The early Christian connection with Rome is further strengthened by the presence of St. Peter and St. Paul at each end of the heavenly realm who were both martyred in Rome. Pope Leo I (440-461 CE) said that St. Peter and St. Paul replaced Romulus and Remus as Rome's protecting patrons (Webb, 2010). Furthermore, the presence of early Church Fathers whose writings explain the foundation of the Church through apostolic succession and the importance of the Eucharist as the Real Presence of Jesus Christ connect the Disputà with the early Christian period.

Julius' involvement in rebuilding St. Peter's Basilica connected him with the early Christian Emperor Constantine the Great (r. 306-337 CE) who initially built St. Peter's and conducted an extensive building

\footnotetext{
21 The identification as Judas Maccabeus is based on Dante, Paradisio, 18.40 (Taylor, 2009, p. 124, note 173). This identification was also proposed by Hersey (1993, p. 136). Dante sees his spirit in the Heaven of Mars with other heroes of the true faith. The presence of the military hero, Judas Maccabeus, may be a reference to the military achievements of Julius II (Beck, 1993, p. 60).
} 
campaign to turn pagan Rome into the Christian capital of the Roman Empire. ${ }^{22}$ Julius commissioned Bramante to demolish the Old St. Peter's and replace it with a new building. The foundation stone was laid in 1506. The reconstruction of St. Peter's unites Julius II with the early Christian days of Rome. From its first days, St. Peter's was the pilgrimage site for St. Peter and the seat of papal authority.

The Disputà, through its display of early Christian iconography refers to the early Christian period when the Church was first formed, when the Eucharist as the Real Presence was first established, and when the ground rules for the leader of the Church were first confirmed through apostolic succession. All figures are united in Eucharistic Adoration, presenting the Eucharist as the heavenly bread of life and as the glorified flesh of Jesus Christ that leads to salvation and eternal life which is the essence of Catholic doctrine found throughout Church history. The early Christian iconography of the Disputà, establishes the legitimacy of the Catholic Church and Rome as the supreme seat of Christian authority.

\section{References}

Ambrose. On the sacraments (De Sacramentis).

Ambrose. (c. 387 CE) Letter to Horontianus.

Armenio, P. V. (2006). The history of the church: A complete course (The Didache Series). Woodridge, Il.

Augustine (c. 390s CE). Exposition of the psalms.

Beck, J. H. (1993). Raphael: The Stanza Della Segnatura. New York: George Braziller.

Beckwith, J. (1979). Early Christian and Byzantine art. New Haven and London: Yale University Press.

Boorsch, S. (1982/83). The building of the vatican, the papacy and architecture. The Metropolitan Museum of Art, Bulletin Winter, 3 , $1-67$.

Catechism of the Catholic Church. (1995). New York: An Image Book, Doubleday.

Chrysostom, John. (Fourth century CE). Homilies on the Gospel of John.

Gombrich, E. H. (1972). Symbolic images, studies in the art of the renaissance. London: Phaidon.

Graber, A. (1968). Christian iconography, a study of its origins. Princeton: Princeton University Press.

Gutman, H. B. (1941). The Medieval Content of Raphael's "School of Athens.” Journal of the History of Ideas, 2(4), 420-429.

Gutman, H. B. (1942). Raphael’s Disputa. Franciscan Studies, 2(1), 35-48.

Hardon, Fr. J. A. (1997). The history of Eucharistic Adoration. Oak Lawn, Ill.: Marian Publishers.

Hersey, G. L. (1993). High renaissance art in St. Peter's and the Vatican: An interpretive guide. Chicago: University of Chicago Press.

Holmes, M. W. (Ed.) (1999). The apostolic fathers. Grand Rapids, Michigan: Baker Books.

Ignatius. (95 CE). Letter to the Corinthians.

Ignatius. (c. $106 \mathrm{CE})$. Letter to the Romans.

Irenaeus. (180-199 CE). Against Heresies.

Jensen, R. M. (2000). Understanding early Christian art. London and New York: Routledge.

Joost-Gaugier, C. L. (2002). Raphael's Stanza Della Segnatura: Meaning and invention. Cambridge and New York: Cambridge University Press.

Josephus. The Antiquities of the Jews.

King, R. (2002). Michelangelo and the Pope's ceiling. New York: Penguin Group.

Krautheimer, R. (2000). Rome, profile of a city, 312-1308. Princeton: Princeton University Press.

Lehmann, K. (1945). The dome of heaven. The Art Bulletin, 27(1), 1-27.

L'Orange, H. P. (1982). Studies on the iconography of cosmic kingship in the ancient world. New Rochelle, New York: Caratzas Brothers.

Luibheid, C. (Trans.). (1987). Pseudo-Dionysius: The complete works. New York: Paulist Press.

\footnotetext{
22 Julius, like Constantine, was instrumental in spreading Christianity. Under Julius, Catholicism spread to new lands that included India, Ethiopia, the Congo, Cuba, Haiti, Puerto Rico, and South America (Joost-Gaugier, 2002, p. 68).
} 
Oberhuber, K. (1999). Raphael: The paintings. New York: Prestel.

Partner, P. (1976). Renaissance Rome, 1500-1559: A portrait of a society. Berkley: University of California Press.

Pfeiffer, H. (1975). Zur Iconographie von Raffaels Disputa. Rome:Università Gregoriana Editrice.

Pope-Hennessy, J. (1970). Raphael (The Wrightsman Lectures under the auspices of the New York University Institute of Fine Arts,

IV). New York: New York University Press.

Reale, G. (1998). Raffaelo La "Disputa": Una interpretazione filosofica e teológica dell'affresco con la prima presentazione analítica dei singoli personaggi e dei particolari simbolici e allegorici emblematici. Milan: Rusconi Libri.

Roberts, A., Donaldson, J., \& Cleveland Coxe, A. (Eds.). (1885). Ante-Nicene Fathers (Vol. 1). (M. Dods \& G. Reith, Trans.). Buffalo, NY: Christian Literature Publishing Co.

Rowland, I. D. (2005). The Vatican Stanze. In M. B. Hall (Ed.), The Cambridge Companion to Raphael (p. 99). Cambridge and New York: Cambridge University Press.

Singer, C. L. (1998). The renaissance in Rome. Bloomington: Indiana University Press.

Taylor, P. (2009). Julius II and the Stanza Della Segnatura. Journal of the Warburg and Courtauld Institutes, 72, 103-141.

Temple, N. (2011). Renovatio Urbis: Architecture, urbanis and ceremony in the Rome of Julius II. New York: Routledge.

Tertullian, (200 CE). The Demurrer Against the Heretics.

Vasari, G. (1568). Le vite de’più eccellenti pittori, scultori ed architettori.

Walford, H. (Trans.). (1881). The letters of S. Ambrose, Bishop of Milan. London: James Parker and Co.

Wallace, W. E. (Ed.). (1995). Michelangelo, selected scholarship in English: The Sistine Chapel. New York: Garland Publishing.

Webb, M. (2010). The churches and catacombs of Early Christian Rome: A comprehensive guide. Eastbourne, Great Britain and Portland, Oregon: Sussex Academic Press. 